\title{
Energy Saving: Views and Attitudes among Primary School Students and Their Parents
}

\author{
Ioanna Zerinou ${ }^{1}$, Evangelia Karasmanaki ${ }^{1}{ }^{(D}$, Konstantinos Ioannou ${ }^{2}\left(\mathbb{D}\right.$, Veronika Andrea ${ }^{1}(\mathbb{D}$ \\ and Georgios Tsantopoulos $1, *$ (D) \\ 1 Department of Forestry and Management of the Environment and Natural Resources, \\ Democritus University of Thrace, 68200 Orestiada, Greece; izerinou@fmenr.duth.gr (I.Z.); \\ evagkara2@fmenr.duth.gr (E.K.); vandrea@fmenr.duth.gr (V.A.) \\ 2 Forest Research Institute, NAGREF, Hellenic Agricultural Organization Demeter, 57006 Vasilika, Greece; \\ ioanko@fri.gr \\ * Correspondence: tsantopo@fmenr.duth.gr; Tel.: +30-25-5204-1118
}

Received: 16 July 2020; Accepted: 25 July 2020; Published: 1 August 2020

check for updates

\begin{abstract}
The ongoing economic development and prosperity have led not only to the exhaustion of the planet's natural resources but also to numerous environmental problems. To address these problems, it is necessary that more individuals adopt energy saving practices while promoting alternative energy sources. In other words, future generations ought to adopt behaviors that will involve the sustainable management of energy. To that end, sustainable education can create citizens who not only have knowledge and awareness about the environment and the severe environmental issues but are also willing to take action to address these issues. Hence, the aim of the present study is to investigate the environmental attitudes and behaviors among primary school students and their parents in the municipality of Orestiada, in Greece. To achieve this objective, a structured questionnaire with closed-ended questions was used. Results showed that both students and parents had adequate levels of environmental awareness while their beliefs were translated into actual behaviors as they had adopted, to a significant extent, energy saving habits and practices.
\end{abstract}

Keywords: primary education; attitudes to renewable energy sources; sustainable education; environmental awareness and attitudes; students' and parents' environmental behavior; citizenship; questionnaire survey

\section{Introduction}

The appearance of man on Earth and the subsequent economic development have led to the degradation of the environment because the economic development of societies has been largely based on the energy produced from fossil fuels such as petrol, diesel, and carbon, whose mismanagement, however, has resulted in major environmental problems. The gradual increase in temperature was caused by the increasing rates of greenhouse gas emissions that occurred during the transition from rural to industrial society. Man-made global warming has been occurring since the Industrial Revolution, whereas the interest in renewable energy sources became strong during the oil crisis of the 1970s. In the following decade, when people finally became aware of the global environmental problems, the use of renewables was established. The development of renewable energy sources comprises an effective and environmentally responsible alternative to fossil fuels because it can decrease the levels of pollution immediately [1]. For this reason, environmental policies promote renewable energy applications as the key to lowering $\mathrm{CO}_{2}[2]$.

To put this differently, conventional energy sources are non-renewable and will eventually run out, but their use will further harm the environment until the exhaustion of their reserves. Conversely, 
renewable energy is derived from natural resources such as the sun and wind, which are abundant in our natural environment and can never run out, as they replenish themselves without depleting the planet's resources. In addition, renewables are environmentally benign since they release relatively low levels of carbon dioxide or other climate-harming gases into the atmosphere [3]. What is more, the rational use of renewable sources encompasses energy saving and environmental protection so that human needs can be met sustainably both now and in the future [4].

Since the dawn of the new millennium, more and more governments are turning to renewables in order to address the challenges posed by climate change and to meet the increasing energy needs of mankind [5]. If, however, one considers that modern living requires greater use of energy, resulting in further environmental damage, it becomes apparent that efficient energy use by individual consumers should not be underestimated. Energy saving and rational use of energy are vitally important not only for safeguarding the environment, but also for saving energy resources. At the same time, sustainable development comprises a tool for tackling the phenomenon of climate change and preventing worst-case scenarios [6].

In order to achieve sustainable development, it is necessary that "active" citizens integrate economic, social, and environmental views into their decision-making. At the same time, citizens ought to have a strong sense of responsibility and be informed about the problems in their local area while participating actively and in a democratic manner in society and environmental protection [7]. Environmental education programs can play an important role in students' behavior and lifestyles as they promote students' critical thinking and action while raising their awareness collectively as society members [8]. As a result of attending such programs, students acquire a global perspective on environmental problems [9]. The purpose of a sustainable school is to create a learning community based on interaction and the exchange of information, experiences, and ideas through its content and pedagogy as well as to form a new culture and a new lifestyle based on the improvement of life quality. Our future is reliant on the energy education provided for all citizens. To prepare students to build a sustainable future, schools should provide them with knowledge, skills, and values that will help them become autonomous citizens capable of drawing conclusions on technology types and social organization [4]. Attitudes are not shaped and cultivated only at school, but also in students' direct environments, in their families. This means that students adopt their family's value system and attitudes towards particular matters while they are subject to the influence of their parents, who either willingly or unwillingly become behavior examples for their children [10].

Hence, the main aim of the present study is to investigate the environmental attitudes among primary school students and their parents. In addition, this study seeks to indicate the behaviors and daily habits of both students and parents as well as to examine whether the stimuli the students have received through education have affected their environmental behavior.

\section{Theoretical Background}

The appearance of man on Earth signified the beginning of environmental degradation, which was caused by the fulfilment of man's increasing energy needs. The heedless use of fossil fuels together with industrial development have led to various environmental problems threatening the sustainability of the natural environment. Since the 1960s the scientific community has pointed to the alarming environmental issues caused by intense industrial and economic development. In response to the environmental problems and scientists' warnings, the environmental movement was developed and redefined the notions of development and progress in ways that reduced environmental impacts. Environmental education, nonformal education, and the institution of the family are required to shape a population that will have information and awareness about environmental problems and to change attitudes towards the management of natural resources and energy use. 


\subsection{Environmental Attitudes and Energy Saving}

Energy was fundamental to the development of human society, but to pursue this development humankind has exhausted the planet's mineral wealth and disrupted the environmental balance. Consequently, the quality of life has deteriorated while our planet's sustainability is threatened. Humanity is facing now multiple environmental problems such as the depletion of natural resources and climate change, which is a rather composite phenomenon involving issues like water scarcity, soil degradation, environmental migration, and human health hazards. According to studies, the average temperature on the surface of the Earth has increased by $0.74{ }^{\circ} \mathrm{C}$ in the last hundred years. This rise translates into a lower number of very cold days and nights and to more hot days and nights. Loukas et al. [11] noted that studies tend to focus on temperature variations but ignore changes in the distribution of glaciers and soil processes like drainage ability and vegetation. In addition to the changes in the quantities of rainfall and snowfall, the spatial distribution of rainfall is most likely to affect human health and migration.

The Paris Agreement on climate change was the first universal and legally binding global agreement on the climate, and it was signed on 22 April 2016 and ratified by the European Union on 5 October 2016. In particular, the Paris Agreement set the long-term objective to keep "global temperature rise this century well below 2 degrees Celsius above pre-industrial levels and to pursue efforts to limit the temperature increase even further to 1.5 degrees Celsius." This objective is in compliance with the targets of the European Union regarding "keeping, protecting and improving the quality of the environment" (Official Journal of the European Union) [12]. If the world community is to achieve the objective of the Paris Agreement, abrupt reductions in gas emissions are necessary, meaning that emissions need to decrease from 40 million tons of carbon dioxide in 2020 to five million tons of carbon dioxide in 2050, thereby falling to zero by 2100 [13].

\subsubsection{The Use of Renewable Energy Sources}

Society's increasing energy needs and the approaching depletion of fossil fuels impel the global community to accelerate the deployment of renewable energy sources using the argument that renewables can be used without the danger of exhaustion while ensuring the prosperity of the natural environment. Indeed, both policy makers and researchers regard renewable energy as an optimal solution to environmental issues, especially those caused by fossil fuels and nuclear power [2].

As already mentioned, the oil crisis in 1973 with the spiraling increase in oil prices marked the end of cheap energy and sparked the interest in renewable energy sources. During the early years of its deployment, renewable energy was rather expensive because its application was still in the experimental phase [14]. However, in the following decade the intensification of environmental problems brought the establishment of renewable energy and over the last years it has been observed that renewables are increasingly being used for energy production in developed countries [4]. Indicatively, biomass may become a major heat source in many countries and a sustainable energy solution [15], while wind energy is considered a mature energy production technology [16]. Tampakis et al. [17] found that knowledge on climate change could account for citizens' positive attitudes towards renewable energy sources. It is clear, therefore, that policies should focus on innovative research on renewable energy in order to reduce our dependence on fossil fuels and tackle environmental issues [5].

\subsubsection{Domestic Emissions}

Individual consumers' efficient use of energy as a means to decrease energy consumption should not be overlooked. According to Hertwich [18], daily habits are a notable factor in energy saving, even though individual consumers perceive environmental knowledge as complicated. Interestingly, household appliances, transport, and food, the main priorities of a family, are responsible for as much as $70 \%$ of environmental impacts [19]. This was also confirmed by Hertwich et al., who estimated that $72 \%$ of greenhouse gas emissions is ascribed to energy consumption in households [20]. Faced with 
the greenhouse effect, it becomes urgent to take action. As Pacala et al. [21] stated, in order to prevent catastrophic climate change, it is of the utmost importance to lower carbon dioxide levels to seven billion tons a year for the next 50 years.

Given that modern living demands greater energy consumption at the expense of the environment, human behavior and environmental behavior, specifically, need to change in order to shape a "healthy environment" for both present and future generations. A citizen with environmental awareness can be defined as someone who is aware of environmental issues and, since he or she views the environment as a matter of personal concern, is willing to "fight" for it [22]. According to Dietz et al. [23], households in the United States are accountable for $38 \%$ of carbon dioxide emissions but with only few changes in daily behavior this percentage can decrease to $20 \%$, which corresponds to 123 cubic tons of carbon dioxide per year. The same research team claimed that the adoption of simple daily habits like transport choices and avoiding leaving electrical appliances on standby mode can reduce notably the levels of carbon dioxide in the atmosphere, thereby buying time for developing new technologies that will further decrease emissions. In a similar study conducted in the United Kingdom, it was calculated that carbon dioxide emissions from households accounted for as high as $26 \%$ of the United Kingdom's total percentage while the emissions could be reduced by simply using the present technology, changing behavior, and reducing the use of fossil fuels for energy production [24].

\subsection{Individual Environmental Behavior}

What makes, therefore, an individual adopt environmentally responsible behavior? What makes someone think critically and have environmental awareness in order to recognize his or her part in environmental protection? Hwang et al. [25] stated that greater environmental knowledge does not necessarily translate into environmentally responsible behavior, and Ishak [26] found that the environmental knowledge that is provided to students through school programs does not suffice. Moreover, other similar studies have revealed that the relationship between environmental knowledge and environmental attitude is a weak one [27,28]. Citizens should, however, develop critical thinking and, most importantly, understand their responsibilities and exercise their rights as both responsible citizens and responsible consumers [29]. Parents and the wider family environment play a significant role in shaping responsible citizens because their attitudes and values, being more important than knowledge, exert great influence on children's attitudes [30]. In addition, schools and environmental education programs not focusing exclusively on the acquisition of environmental knowledge but instead emphasizing emotional and psychomotor objectives comprise another notable factor in shaping pro-environmental behaviors and environmentally responsible attitudes among students. Moreover, in order to enable citizens to understand the danger resulting from the scarcity of energy sources, raise their environmental awareness, and enhance their participation in pro-environmental actions, society should ensure that individuals receive the necessary relevant information [31].

\subsubsection{Education on Sustainable Development}

Global concerns about environmental issues have increased the interest of the public, and there is consensus on the need to shape environmentally conscious citizens. As school reflects the problems our society faces, it assumes the important role of changing citizens' thinking and promoting environmental regulations while encouraging individuals to adopt environmentally responsible behavior. In other words, education can help shape environmentally responsible behavior, raise environmental awareness, and encourage energy saving. The strong link between environmental education and environmental communication can enable the dissemination of environmental information more effectively with the sole aim of promoting environmental sustainability. That is because environmental communication is the process that can promote more appropriate environmental decisions and legislations as it is a wider term than environmental education [32].

The future citizen should be educated both inside and outside the framework of school in order to have awareness about the environment. To that end, suitable educational programs are required 
so that students acquire critical thinking about climate change and other environmental issues that are caused by human activities [33]. At the same time, it has been argued that through education on sustainability and on the environment young people may become the leaders of tomorrow who will contribute to research on environmental protection [34]. For this reason, the content of this type of education should contribute to shaping positive attitudes, especially towards the management of the natural environment [35].

The emergence and development of environmental education was linked to the environmental movement of the 1960s and 1970s. In the 1970s, an unprecedented mobility occurred in terms of environmental education, with the most important events being the International Workshop on Environmental Education conducted in Belgrade (1975) and the Intergovernmental Conference on Environmental Education held in Tbilisi (1977). From the 1990s and onwards, environmental education has been defined by the notion of sustainability, which integrates the environment, society, and economy [36]. More than four decades after the emergence of environmental education, the sustainable school has transcended the tight context of "green" school and is closely related to quality education while it seeks to transform school into a community of interaction and to experience exchange among all participants. Environmental awareness can be raised through nonformal education, that is, through the dissemination of environmental knowledge, news, or discussions as well as through the information the students acquire from the media in their everyday lives. In particular, the greatest part of the population has access to the media and resorts to them for their information. The power of the media is considered immense not only because the media inform citizens about the major environmental issues but also because they are able to shape public opinion. This can prove to be quite useful, especially when it comes to encouraging citizens to participate in programs of managing and protecting natural resources at the local level [37]. For this reason, journalists must receive environmental education in order to cover environmental topics as well as to present the actual socioeconomic aspects of environmental issues and possible action paths that, in turn, can raise public environmental awareness [32]. All these were articulated in the Intergovernmental Conference on Environmental Education in Tbilisi, where it was stated that "Environmental education must be offered to people of all ages and at the levels of both formal and non-formal education".

The lack of relevant information, however, has a negative effect on shaping individual consumers' behavior [26]. In a study carried out in Hong Kong, one of the most polluted cities in the world, it was found that although the majority of students believed that it was their duty to protect the environment and recycle at both school and home, their actual behavior deviated from their stated behavior [38]. In addition, more than $90 \%$ of university students in Chile sought to save energy and water by switching off the lights and turning off the tap, whereas only a few bought organic products [39]. In another study, it was indicated that $60 \%$ of students attending the last grade of primary school and $80 \%$ of students in the last grade of secondary school were knowledgeable about air pollution but neither recognized the need to reduce the use of fossil fuels nor preferred public transport [40]. In a large-scale study investigating the perceptions of 3708 school students in New York, it was revealed that a high share of students (by 73\%) was concerned about energy issues but considered themselves as having inadequate knowledge and skills to help resolve them [41]. In addition, most students in a Turkish school were worried about environmental problems but only $12 \%$ of them were members of an environmental organization [42].

\subsubsection{The Role of Family in Shaping Environmental Attitudes}

At this point, it should be pointed out that students come to school with a system of values and attitudes that has already been shaped by their family environment, while it has also been shown that family plays a primary role in shaping students' attitudes. Interestingly, a study in Greece revealed that even though students express interest in the environment and its problems, their environmental attitudes tend to diminish over time [43] because the other family members do not express pro-environmental attitudes on a daily basis. A similar observation was made in a study carried 
out in Great Britain in which students stated their interest in environmental protection but found it difficult to keep on recycling since their parents were not always willing to recycle [44]. In another study conducted in the Netherlands, it was indicated that the messages the students received from school and family were often conflicting, as most students' families owned at least one car and students rarely covered any distances on foot [45]. Likewise, in New Zealand only $3 \%$ of female and $28 \%$ of male students aged 13-17 years used their bicycles to go to school, even though their houses were located fewer than four kilometers away from their school [46]. In Malaysia, primary and secondary students' parents used cars to make sure their children got to school safely despite acknowledging that walking and cycling are beneficial to health [47]. It can be stated that if the family exhibits a negative environmental behavior, children are less likely to express pro-environmental behaviors while existing environmentally friendly behaviors can diminish.

Environmental behavior starts to develop in childhood, and, for this reason, parents should provide their children with the appropriate experiential experiences because stimuli and experiences help the child to develop values, attitudes, and behaviors. According to Chawla [48], habits like family walks in the forest or activities in nature can help parents serve as role models and encourage children to shape positive attitudes towards the environment. A relevant study indicated that children are affected by experiences in nature such as hiking, camping, and fishing, and these experiences can induce them to become environmentally responsible citizens in the future [49]. In addition, the long-term exposure to nature during summer camping connects children emotionally to nature and prompts them to develop strong environmental beliefs and eventually adopt environmentally friendly behaviors [50]. In addition, primary school students in New York reported that they collect or recycle the garbage they produce during nature excursions with their parents [51]. The same observations were made in Bulgaria where primary school students in urban and semi-urban areas expressed their preference for activities in nature that require direct involvement with environmental protection, such as shaping and maintaining green spaces or planting and taking care of trees [52]. Parents who realize the role of the family in shaping environmentally conscious citizens [53] can provide their children with experiences to help them come in contact with the natural environment, since through this contact children are expected to form positive environmental attitudes and behaviors [10].

Parents' consumer behavior and purchase decisions are also pedagogical actions, as it has been shown that parents serve as examples for children. Indicatively, it is interesting that girls tend to imitate the environmental behavior of their fathers while boys tend to imitate their mothers [54]. Moreover, parents' personal participation in environmental activities such as recycling or purchasing products contained in recyclable packages can prompt children to commit to environmental activities [55]. In addition, Walker et al. [56] confirmed that the family's environmental behavior in terms of recycling, consumption patterns, as well as energy and water saving, exerts great influence on children's environmental attitudes. The same conclusion was drawn by Palmer [57], who noticed that children's participation in pro-environmental actions and activities like recycling and water saving is shaped by the effects of parents' direct and indirect actions. The effect of family actions on the child was also confirmed by a study in which Greek students reported that they recycle packages and batteries because their parents were also doing so [58].

On a general note, knowledge, awareness, and the ability to evaluate environmental problems can drive individuals to participate actively in the improvement and protection of the environment. The desire to act for the environment, however, depends on a plethora of personal factors. Besides cognitive experiences, emotional experiences and personal factors like creating a family and acknowledging the ecological problem can induce individuals to act for the environment. In a study conducted in the United Kingdom, it was observed that individuals who had their first child and were already concerned about the environment before having their own family, expressed a desire to adopt pro-environmental behaviors such as switching off the lights when leaving a room, buying products contained in recycled paper, or covering short distances on foot [59]. Moreover, the same study revealed that young mothers are likely to opt for environmentally friendly detergents, motivated 
by their wish to protect their children from dangerous chemical substances. Furthermore, families in Greece were willing to invest in renewable energy in order to contribute to environmental protection and to pay less money for electricity and water bills [60]. In Portugal, families with children had a greater inclination to participate in recycling programs in which they would be entitled to some discount if they recycled packages at the supermarket. However, the same study showed that childless couples and unmarried individuals were not inclined to participate in such programs [61]. According to Gramm-Hanssen [62], in Denmark adolescents consume 20\% more electricity than their parents during the time they live with their parents, but their energy and water-saving patterns change when they begin to pay their own bills. Another study in Denmark showed that even though parents and children have similar pro-environmental behaviors like opting for organic products, parents are more committed to environmental protection and seek to save energy [63].

If we wish to protect the environment, we need to transform our environmental beliefs into action and move in the direction of sustainability by reducing the household's impact on the environment. In addition, it is essential to enhance environmental programs at school [64]. That is because children play a catalytic role and can promote environmental knowledge and behavior among family and society members [65]. Hence, encouraging students to attend such programs can have far-reaching effects on society. In terms of adults, most people claim that they are interested in the environment, and therefore it is up to them to understand the environmental catastrophe and decide what they want for future generations [66].

Having discussed the existing information and findings from the relevant literature, the significance of the topic of this paper has been highlighted. That is, in view of the relevant literature it is clearly shown that children shape environmental beliefs and attitudes in response to the stimuli they receive from their families and school. At the same time, future generations will play a critical role in the protection of our planet, and this role underlines the importance of dedicating more attention and resources to investigating their environmental attitudes. Hence, this study can make a significant contribution to this direction as it seeks to examine the environmental views and behaviors of both students and their parents. The findings will not only serve to confirm or contradict the findings of previous research works but will also add further insights. In specific, the contribution of school to students' environmental attitudes will be investigated and, at the same time, students' attitudes can be compared to those of their parents.

\section{Materials and Methods}

\subsection{Study Area}

The primary schools located in the conurbation of Orestiada comprised the area of study. The municipality of Orestiada is one of the five municipalities that are located in the Prefecture of Evros and belongs to the Regional Unit of Eastern Macedonia and Thrace in Greece. In the municipality of Orestiada, there are 16 primary schools, including the Special School and the primary school in the village of Thourio whose operation is suspended. Orestiada is located in the northernmost part of Greece and borders Bulgaria to the north and Turkey to the east. The seat of the municipality is the town of Orestiada, which has a population of 18,426 citizens, according to the decennial population census that was conducted in 2011. It is also worthwhile to note that Orestiada is the most recently established town in Greece and was built after the Lausanne Treaty in 1923.

\subsection{Data Collection}

To collect the data for the study, the questionnaire was considered the most appropriate research instrument and a questionnaire with closed-ended items was designed. In a questionnaire survey, the respondent is required to answer a set of pre-established questions with specific answers on a particular topic. The questionnaire is considered an effective instrument because it can collect a large volume of data from a high number of respondents and the collected data can be analyzed easily and 
quickly. It should also be noted that the questionnaire is characterized by anonymity, which makes respondents willing to complete it [67].

The questionnaire used in this study was designed specifically to address the aims of the present research and the content of the questions took into account the relevant literature, which was presented in the previous sections. It was completed by students attending the fifth and sixth grades of primary school and was well adjusted for students in primary education between the ages of eleven and twelve years old. In addition, it was formulated in a way that students would need about 15-20 min to complete it. Hence, the students were required to fill in individual questionnaires that included pre-coded questions accompanied by a series of ready-made answers. At the same time, the questionnaire that would be completed by the parents of the same students was very similar. Although the content of both questionnaires was the same, the questionnaire addressed to students was phrased in a more simple and easy-to-understand manner to ensure that all students would comprehend the questions. In particular, the chosen vocabulary and the formulation of the questions were such that they would decrease the chances of misinterpretation. Most items were closed-ended questions because the pre-coded form facilitates the indexation of the questionnaire, the classification of answers, and computer processing [68]. Moreover, the study participants were required to choose one of the given answers without having to write any text, which they would possibly find tiresome. It is important to note that a pilot study of the questionnaire was conducted to check both the suitability of the questionnaire and the reliability and validity of the attitude scale.

In terms of the content of the questionnaires addressed to students and their parents, both had the same length and contained 26 items, but there were some minor differences between the two questionnaires. The first section in both questionnaires gathered information on respondents' demographic characteristics, but the questionnaire addressed to parents included some additional questions on parents' occupations, number of children, family status, and ages. In the questionnaire addressed to students, the same section collected information on students' genders and places of residence. Then, both questionnaires explored respondents' levels of agreement with some general statements about the environment (for instance, "Do you agree that natural resources are limited?", "Are you satisfied with the situation of the environment?"). However, students were additionally asked whether they have participated in an environmental education program at school. Next, both questionnaires examined participants' environmental habits as well as environmental attitudes (such as behavioral patterns relating to energy and water saving, energy status of respondents' homes, energy installations). In addition, students' questionnaire included items examining their basic knowledge on climate change, renewable energy, and fossil fuels.

Finally, to implement this study a census-based approach was preferred to other research methods. A census seeks to list all elements in a group and to capture some of their characteristics. This group is often a national population; however, it may also be households, students attending one or more schools, farms, books in a library, and so forth. In this study, the target population consisted of all students attending the fifth and sixth grades of primary schools that are located in the municipality of Orestiada. According to the census, in total there are 16 primary schools in the municipality of Orestiada. However, these 16 primary schools include the Special School and the primary school in the village of Thourio, whose operation is suspended. The final number of primary schools in the municipality of Orestiada that could participate in this study was thus 12. It was considered adequate to include in this study half of these primary schools. That is, the study subjects were fifthand sixth-grade students in six out of the total twelve primary schools located in the municipality of Orestiada. In total, 128 questionnaires were completed by students attending the fifth and sixth grades of six primary schools, and the same number of questionnaires was completed by the parents of these students. It is also important to note that the present research had to comply with the relevant legal and ethical standards, and thus it was first approved by the Pedagogical Institute and the Greek Ministry of Education and Religious Affairs. These authorities examined the content of the questionnaires and the application to perform the study. The data were collected from May 2017 to June 2017. 


\subsection{Statistical Processing}

To analyze the collected data, descriptive statistics and the non-parametric Friedman test were carried out. The non-parametric Friedman test is used to compare the values of three or more correlated groups of a variable. The distribution of the Friedman criterion is $x^{2}$ with degrees of freedom $D F=k-1$, where $\mathrm{k}$ represents the number of groups or samples. This criterion classifies the values of the variables for each subject separately and estimates the mean rank of the classified values for each variable [69].

\section{Results}

The results of this study are presented in two sections. The first section involves students' views and attitudes, while the second section includes students' parents' views and attitudes towards a series of environmental issues. In specific, Section 4.1, "Students' views and attitudes," presents information on students' demographic characteristics, students' satisfaction with the situation of the natural environment, and their views on the availability of natural resources, daily habits, and the contribution of information sources to the respondents' acquisition of environmental knowledge. Section 4.2, "Parents' views and attitudes," provides information on participants' demographic characteristics, their satisfaction with the natural environment, their views on the availability of natural resources, daily habits and practices, trust in bodies, and the information sources parents use for their daily information.

\subsection{Students' Views and Attitudes}

Students' views and attitudes towards specific topics were examined. These topics involved satisfaction with the situation of the natural environment, the availability of natural resources, participation in an environmental program at school, the contribution of various information sources to the acquisition of environmental knowledge, students' and their families' daily habits regarding energy and water management, the energy situation at students' homes and the use of transport.

\subsubsection{Demographic Characteristics}

In terms of students' genders, it can be seen in Table 1 that there were slightly more male (51.6\%) than female $(48.4 \%)$ respondents in the sample. As for the place of residence, there was almost an equal distribution with a slight prevalence of rural dwellers (50.8\%) (Table 2). Students were also asked whether they have participated in an environmental program at school and, as shown in Table 3 , the majority of students, by $60.9 \%$, stated they have done so.

Table 1. Percentages regarding students' genders.

\begin{tabular}{cc}
\hline Male & Female \\
\hline 51.6 & 48.4 \\
\hline
\end{tabular}

Table 2. Percentages of students' places of residence.

\begin{tabular}{cc}
\hline Urban Residence & Rural Residence \\
\hline 49.2 & 50.8 \\
\hline
\end{tabular}

Table 3. Percentages relating to students' participation in an environmental program at school.

\begin{tabular}{cc}
\hline Yes & No \\
\hline 60.9 & 39.1 \\
\hline
\end{tabular}

In terms of students' parental education level, Table 4 shows that $30.5 \%$ of fathers and $34.4 \%$ of mothers were high school graduates. Moreover, $20.3 \%$ of fathers and $18 \%$ of mothers were university 
graduates. However, only, $8.6 \%$ of fathers and $7 \%$ of mothers were elementary school graduates, while as few as $5.5 \%$ of both parents held master's degrees.

Table 4. Percentages of the students' parental educational levels.

\begin{tabular}{ccc}
\hline & Father & Mother \\
\hline Primary school graduate & 8.6 & 7.0 \\
Secondary school graduate & 12.5 & 3.9 \\
High school graduate & 30.5 & 34.4 \\
Vocational senior high school graduate & 14.1 & 18.8 \\
Technical Institution graduate & 8.6 & 12.5 \\
University graduate & 20.3 & 18.0 \\
Master's degree holder & 5.5 & 5.5 \\
\hline
\end{tabular}

Table 5 shows parents' professions. A substantial proportion of the students' fathers (39.8\%) and mothers $(18 \%)$ were employed in the public $(26.6 \%)$ sector. An appreciable proportion of fathers $(14.8 \%)$ and mothers $(17.2 \%)$ were employed in the private sector. In addition, a considerable percentage of mothers $(32.8 \%)$ was not engaged in paid work and was involved with the household duties. Remarkably, only $6.3 \%$ of fathers were unemployed and very few parents were pensioners.

Table 5. Percentages regarding students' parents' occupations.

\begin{tabular}{ccc}
\hline & Father & Mother \\
\hline Employed in the public sector & 39.8 & 18.0 \\
Employed in the private sector & 14.8 & 17.2 \\
Freelancer & 21.9 & 10.2 \\
Farmer & 12.5 & 6.3 \\
Unemployed & 6.3 & 14.1 \\
Pensioner & 4.7 & 1.6 \\
Household & 0.0 & 32.8 \\
\hline
\end{tabular}

4.1.2. Students' Satisfaction with the Situation of the Natural Environment and their Views on the Availability of Natural Resources

Students' satisfaction levels with the situation of the natural environment were examined. As shown in Table 6, it is interesting that only half of the students were satisfied with the environment's situation.

Table 6. Percentages of respondents' satisfaction levels with the state of the natural environment.

\begin{tabular}{ccccc}
\hline Not at All & Slightly & Moderately & Very Much & Extremely \\
\hline 3.9 & 6.3 & 38.3 & 43.0 & 8.6 \\
\hline
\end{tabular}

Respondents were then asked whether they agreed with the statement that natural resources (such as crude oil, drinking water, etc.) are limited. Most students (by 63.3\%) agreed or strongly agreed that natural resources are limited, while only $14.9 \%$ of students disagreed with the statement (Table 7).

Table 7. Students' levels of agreement with the statement that natural resources are limited.

\begin{tabular}{ccccc}
\hline Strongly Disagree & Disagree & Neither Agree nor Disagree & Agree & Strongly Agree \\
\hline 4.7 & 10.2 & 21.9 & 41.4 & 21.9 \\
\hline
\end{tabular}

\subsubsection{Students' Daily Habits}

The relevant literature has focused consistently on students' attitudes towards various environmental topics, such as recycling, climate change, energy, water saving, and so forth. In this study, 
students' daily habits and practices were investigated. To examine the existence of statistical difference among students' responses, the non-parametric Friedman test was applied (Table 8). According to the results of the test, turning off the tap while brushing teeth ranked first (mean rank 11.98), followed by pulling down the shutters in winter (mean rank 11.23), and having a bath without filling the bathtub with water (mean rank 10.90). Conversely, the lowest-ranked environmental practices were keeping windows closed on hot summer days (mean rank 5.84) and using a pressure cooker at home (mean rank 5.29).

Table 8. The application of the Friedman test for ranking students' daily environmental practices and habits.

\begin{tabular}{cc}
\hline & Mean Rank \\
\hline Having decided what to eat before opening the fridge door & 7.04 \\
Using a dishwasher at home & 7.53 \\
Using a pressure cooker at home & 5.29 \\
Switching off the lights when leaving a room & 10.48 \\
Pulling down the shutters at night in winter & 11.23 \\
Always unplugging chargers when not using them & 8.92 \\
Drying clothes without placing them on radiators for heating & 9.72 \\
Running the dishwasher on full loads & 7.23 \\
Parents using the oven only in the morning or at night in summer & 7.35 \\
Closing the windows on hot summer days & 5.84 \\
Ventilating the house only at night on hot summer days & 6.33 \\
Turning the shower off while lathering up or washing hair & 10.61 \\
Turning off the tap while washing teeth & 11.98 \\
Having a bath without filling the bathtub with water & 10.90 \\
Watering plants exclusively with a watering can & 6.74 \\
Recycling the used packages & 8.92 \\
\hline N = 128, Chi-Square = 506.129, df $=15, p<0.001$. &
\end{tabular}

Then, respondents were asked how often they take the stairs in their building. As shown in Table $9,32 \%$ of respondents reported that they always take the stairs, while the question could not apply to slightly over half of the respondents (by $51.6 \%$ ) because they lived in single-family homes.

Table 9. Percentages regarding the use of the stairs in the building.

\begin{tabular}{ccccc}
\hline Never & Once or Twice a Day & 3-4 Times a Day & Always & I Live in a Single-Family Home \\
\hline 3.9 & 3.1 & 9.4 & 32.0 & 51.6 \\
\hline
\end{tabular}

Participants were also asked what they do when they feel cold, even though the windows in their house are closed and the heating is on. Opinions on this matter were divided with $53.9 \%$ of students stating that they put on another layer of clothes and with $46.1 \%$ stating that they turn the heating up (Table 10).

Table 10. Percentages regarding students' actions when feeling cold although the heating is on.

\begin{tabular}{cc}
\hline Turning the Heating Up & Putting on Another Layer of Clothes \\
\hline 46.1 & 53.9 \\
\hline
\end{tabular}

Students were next asked to what temperature the thermostat is set at their house in winter. As presented in Table 11, a high share of respondents (29.7\%) stated that the temperature is set between $20^{\circ} \mathrm{C}$ and $22{ }^{\circ} \mathrm{C}$, and a considerable share $(18.8 \%)$ reported $18{ }^{\circ} \mathrm{C}-20{ }^{\circ} \mathrm{C}$. However, only $6.3 \%$ answered that the temperature is set higher than $24^{\circ} \mathrm{C}$ and very few (by $1.6 \%$ ) to lower than $18^{\circ} \mathrm{C}$. In addition, an appreciable percentage of respondents $(28.9 \%)$ did not use the radiator for heating at their houses. 
Table 11. Frequencies and percentages regarding the temperatures to which the thermostat is set at students' homes in winter.

\begin{tabular}{ccc}
\hline & Frequencies & Percentages \\
\hline Lower than $18{ }^{\circ} \mathrm{C}$ & 2 & 1.6 \\
$18^{\circ} \mathrm{C}-20{ }^{\circ} \mathrm{C}$ & 24 & 18.8 \\
$20^{\circ} \mathrm{C}-22^{\circ} \mathrm{C}$ & 38 & 29.7 \\
$22{ }^{\circ} \mathrm{C}-24^{\circ} \mathrm{C}$ & 19 & 14.8 \\
Higher than $24^{\circ} \mathrm{C}$ & 8 & 6.3 \\
Not using radiator for heating & 37 & 28.9 \\
\hline
\end{tabular}

Next, the means of transport students use to go to school was examined. As seen in Table 12, the car was used with a frequency of "sometimes to always" by a high share of students (65\%). However, the same frequency was recorded for over half of the students (by 58.6\%) who go to school on foot. Interestingly, $91.4 \%$ never used public transport to go to school.

Table 12. Percentages relating to the means of transport respondents use to go to school.

\begin{tabular}{cccccc}
\hline & Never & A Few Times & Sometimes & Many Times & Always \\
\hline Car & 21.1 & 13.3 & 21.1 & 28.9 & 15.6 \\
Public transport & 91.4 & 4.7 & 2.3 & 0.0 & 1.6 \\
On foot & 22.7 & 18.8 & 15.6 & 22.7 & 20.3 \\
Bicycle & 42.2 & 12.5 & 14.8 & 24.2 & 6.3 \\
\hline
\end{tabular}

To determine participants' ratings regarding the means of transport they use to go to school, responses were ranked using the Friedman test, which highlighted an overall statistically significant difference between the mean ranks of the related groups. According to the test's results (given in Table 13), car was ranked first (mean rank 3.02), whereas public transport ranked in the last position (mean rank 1.51).

Table 13. The application of the Friedman test for ranking respondents' uses of various means of transport to go to school.

\begin{tabular}{cc}
\hline & Mean Rank \\
\hline Car & 3.02 \\
Public transport & 1.51 \\
On foot & 2.86 \\
Bicycle & 2.61 \\
\hline 128, Chi-Square $=126.962, \mathrm{df}=3, p<0.001$
\end{tabular}

Students' energy saving practices regarding the use of domestic appliances were then investigated. In terms of television, most respondents (by 63.3\%) switched off the TV using the power on/off button, whereas $35.2 \%$ left the television on standby mode. Almost the same share $(64.8 \%)$ switched off the laptop pushing the power button, but a lower percentage (22.7\%) left it on standby mode. Interestingly, around half of the students did not own a desktop computer or a stereo (Table 14).

Table 14. Percentages of students' energy saving practices of appliances.

\begin{tabular}{cccc}
\hline & Switching It Off & Leaving It on Standby Mode & Not Owning \\
\hline Television & 63.3 & 35.2 & 1.6 \\
Laptop & 64.8 & 22.7 & 12.5 \\
Desktop & 29.7 & 13.3 & 57.0 \\
Stereo & 41.4 & 10.9 & 47.7 \\
\hline
\end{tabular}


4.1.4. The Contribution of Information Sources to Respondents' Acquisition of Environmental Knowledge

Respondents were also required to evaluate various information sources based on the degree to which each source has helped them acquire information on environmental topics. To detect whether statistical differences occurred among students' responses, statistical analysis was conducted by the non-parametric Friedman test. According to the results displayed in Table 15, school (mean rank 7.55), family (mean rank 6.94), and excursions in nature (mean rank 6.34) were the highest ranked information sources.

Table 15. Application of the non-parametric Friedman test for ranking responses on the contribution of various information sources to the acquisition of environmental knowledge.

\begin{tabular}{cc}
\hline & Mean Rank \\
\hline School & 7.55 \\
Family & 6.94 \\
Friends/classmates & 3.73 \\
Television/radio & 3.92 \\
Internet & 4.39 \\
Magazines/newspapers & 2.43 \\
Environmental programs & 5.14 \\
Excursions in nature & 6.39 \\
Museum exhibitions & 4.49 \\
\hline $\mathrm{N}=128$, Chi-Square $=432.174, \mathrm{df}=8, p<0.001$.
\end{tabular}

\subsection{Parents' Views and Attitudes}

In this section, the results of students' parents' views and attitudes will be presented. The data that were obtained encompassed a variety of topics, such as parents' views on the state of the natural environment, the availability of natural resources, their daily environmental habits and practices, the contribution of information sources to the acquisition of environmental knowledge, the management of energy and water, the energy situation at home, and use of transport.

\subsubsection{Descriptive Statistics}

The descriptive characteristics of the students' parents who took part in the survey are presented in this section. According to Table 16, $73.4 \%$ of the participants were female and $26.6 \%$ were male, and consequently female respondents outnumbered their male counterparts. Additionally, Table 17 tabulates data on respondents' ages. Five out of ten parents were aged between 31 and 40 years, while $39.8 \%$ were aged between 41 and 50 years. Conversely, only $7 \%$ of parents were $51-60$ years and as few as $1.6 \%$ were 30 years.

Table 16. Percentages of respondents' genders.

\begin{tabular}{cc}
\hline Male & Female \\
\hline 26.6 & 73.4 \\
\hline
\end{tabular}

Table 17. Frequencies and percentages regarding respondents' ages.

\begin{tabular}{ccc}
\hline Age & Frequency & Percentage \\
\hline $18-30$ & 2 & 1.6 \\
$31-40$ & 66 & 51.6 \\
$41-50$ & 51 & 39.8 \\
$51-60$ & 9 & 7.0 \\
\hline
\end{tabular}


Table 18 presents respondents' family status, and it can be seen that the strong majority of respondents (by $89.8 \%$ ) was married, while quite low shares of parents were divorced $(6.3 \%)$ or widowed (3.9\%). In terms of children, about half of the participants $(50.8 \%)$ had two children and a share of $12.5 \%$ had more than four children (Table 19).

Table 18. Percentages of respondents' family status.

\begin{tabular}{ccc}
\hline Married & Divorced & Widow-Widower \\
\hline 89.8 & 6.3 & 3.9 \\
\hline
\end{tabular}

Table 19. Percentages regarding respondents' number of children.

\begin{tabular}{cccccc}
\hline 1 Child & 2 Children & 3 Children & 4 Children & 5 Children & 6 Children \\
\hline 19.5 & 50.8 & 17.2 & 7.8 & 3.9 & 0.8 \\
\hline
\end{tabular}

In terms of parents' education levels, only $2.3 \%$ of parents had not completed primary education, while $10.9 \%$ were university graduates and $32.8 \%$ were high school graduates (Table 20).

Table 20. Frequencies and percentages relating to parents' education levels.

\begin{tabular}{ccc}
\hline & Frequency & Percentage \\
\hline Not having completed primary education & 3 & 2.3 \\
Primary school graduate & 12 & 9.4 \\
Secondary school graduate & 10 & 7.8 \\
High school graduate & 42 & 32.8 \\
Vocational senior high school graduate & 9 & 7.0 \\
Vocational training institute graduate & 16 & 12.5 \\
Technical Institution graduate & 16 & 12.5 \\
University graduate & 14 & 10.9 \\
Master's degree holder & 6 & 4.7 \\
\hline
\end{tabular}

As for parents' occupations, considerable shares of parents were employed in the public sector $(27.3 \%)$ and the private sector $(17.2 \%)$. A significant percentage were not engaged in paid work and were occupied with the household $(26.6 \%)$. However, only $7.8 \%$ of respondents were farmers, and as few as $5.5 \%$ were freelancers (Table 21 ).

Table 21. Percentages of parents' occupations.

\begin{tabular}{cc}
\hline Farmer & 7.8 \\
Household & 26.6 \\
Employed in the private sector & 17.2 \\
Pensioner & 0.8 \\
Employed in the public sector & 27.3 \\
Freelancer & 5.5 \\
Crafts/businessman & 0.8 \\
Unemployed & 12.5 \\
\hline
\end{tabular}

4.2.2. Parents' Satisfaction with the Natural Environment and Their Views on the Availability of Natural Resources

First, the respondents were asked whether the natural environment affects our lifestyle. As shown in Table 22, the overwhelming majority of participants (by 94.6\%) agreed and strongly agreed with this statement. In addition, most parents (by $76,6 \%$ ) agreed or strongly agreed that natural resources (such as crude oil, drinking water, etc.) are limited, while only a small share (by $7.1 \%$ ) disagreed or strongly disagreed with this statement (Table 23). 
Table 22. Percentages regarding respondents' degrees of agreement with the statement that the natural environment affects our lifestyle.

\begin{tabular}{ccccc}
\hline Strongly Disagree & Disagree & Neither Agree nor Disagree & Agree & Strongly Agree \\
\hline 0.8 & 0.8 & 3.9 & 35.2 & 59.4 \\
\hline
\end{tabular}

Table 23. Percentages regarding respondents' degrees of agreement with the statement that natural resources are limited.

\begin{tabular}{ccccc}
\hline Strongly Disagree & Disagree & Neither Agree nor Disagree & Agree & Strongly Agree \\
\hline 1.6 & 5.5 & 16.4 & 43.8 & 32.8 \\
\hline
\end{tabular}

\subsubsection{Parents' Daily Habits and Practices}

To investigate the existence of statistical difference among parents' daily habits and practices, the non-parametric Friedman test was conducted (Table 24). According to the results of the test, having a bath without filling the bathtub with water (mean rank 14.78), followed by using pots that match the size of the burner (mean rank 13.64), and switching off the lights when leaving a room (mean rank 13.63) were the most ranked habits. Conversely, adjusting the temperature on the washing machine below $40^{\circ} \mathrm{C}$ received the last ranking (mean rank 6.86).

Table 24. The application of the Friedman test for ranking parents' daily environmental habits.

\begin{tabular}{cc}
\hline & Mean Rank \\
\hline Using pots that match the size of the burner & 13.64 \\
Using a pressure cooker & 9.18 \\
Having decided what to eat before opening the refrigerator door & 7.19 \\
Checking if the roast is ready without opening the oven door & 8.97 \\
Wsing a dishwasher & 6.87 \\
Washing clothes in the washing machine without using the prewash cycle & 9.93 \\
Setting the temperature on the washing machine below $40{ }^{\circ} \mathrm{C}$ & 6.86 \\
Switching off the lights when leaving a room & 13.63 \\
Pulling down the shutters at night in winter & 13.01 \\
Always unplugging chargers when not using them & 9.54 \\
Drying clothes without placing them on radiators & 11.58 \\
Running the dishwasher on full loads & 11.34 \\
Using the oven only in the morning or at night in summer & 8.49 \\
Closing the windows on hot summer days & 10.62 \\
Ventilating the house only at night on very hot summer days & 11.09 \\
Turning off the tap while shaving or brushing teeth & 11.73 \\
Turning the shower off while lathering up or washing hair & 12.43 \\
Having a bath without filling the bathtub with water & 14.78 \\
Watering plants exclusively with a watering can & 8.66 \\
Recycling used packages & 10.46 \\
\hline N = 128, Chi-Square = 397.697, df = 8, $p<0.001$. &
\end{tabular}

Parents were also asked whether they checked the energy label of domestic appliances before buying them. Interestingly, most respondents stated they do so, whereas only one in ten respondents did not check the energy labelling (Table 25). Moreover, four in ten respondents owned domestic appliances that were rated as class A or higher, while only $16.4 \%$ of respondents were not aware of the energy class of their appliances (Table 26).

Respondents were then asked about the kind of light bulbs they use at home. As shown in Table 27, the majority (60.2\%) used compact fluorescent bulbs and a significant share (by 25.8\%) used LED bulbs. 
Table 25. Percentages regarding parents' responses to whether they check the energy label of appliances before purchase.

\begin{tabular}{ccc}
\hline Yes & No & Sometimes \\
\hline 64.8 & 10.2 & 25.0 \\
\hline
\end{tabular}

Table 26. Percentages of respondents' appliance energy classes.

\begin{tabular}{ccccc}
\hline A and Higher & B Class & Below C Class & Other Classes & Do Not Know \\
\hline 42.2 & 13.3 & 2.3 & 25.8 & 16.4 \\
\hline
\end{tabular}

Table 27. Percentages regarding the kinds of light bulbs the respondents use at home.

\begin{tabular}{ccc}
\hline Incandescent Bulbs & Compact Fluorescent Bulbs & LED Bulbs \\
\hline 14.1 & 60.2 & 25.8 \\
\hline
\end{tabular}

Parents' energy saving regarding the use of specific appliances was then investigated. In terms of television, over half of the respondents (by 53.3\%) switched off the TV using the power on/off button. As for the laptop, most respondents (73.4\%) switched it off. Moreover, high shares did not own any desktop computers and stereos (Table 28).

Table 28. Percentages of parents' energy saving uses of appliances.

\begin{tabular}{cccc}
\hline & Switching It Off & Leaving It on Standby Mode & Not Owning \\
\hline Television & 53.1 & 46.1 & 0.8 \\
Laptop & 73.4 & 15.6 & 10.9 \\
Desktop & 27.4 & 15.6 & 57.0 \\
Stereo & 41.4 & 10.9 & 47.7 \\
\hline
\end{tabular}

Parents were next asked to what temperature the thermostat is set in winter. As presented in Table 29, most respondents (by $43 \%$ ) set the temperature between $20{ }^{\circ} \mathrm{C}$ and $22{ }^{\circ} \mathrm{C}$, and a considerable share $(15.6 \%)$ set it between $18{ }^{\circ} \mathrm{C}$ and $20^{\circ} \mathrm{C}$. However, only $1.6 \%$ set it to a temperature higher than $24^{\circ} \mathrm{C}$, and very few $(1.6 \%)$ set it to lower than $18{ }^{\circ} \mathrm{C}$.

Table 29. Frequencies and percentages relating to thermostat temperatures during winter.

\begin{tabular}{ccc}
\hline & Frequency & Percentage \\
\hline Below $18^{\circ} \mathrm{C}$ & 2 & 1.6 \\
$18^{\circ} \mathrm{C}-20^{\circ} \mathrm{C}$ & 20 & 15.6 \\
$20^{\circ} \mathrm{C}-22^{\circ} \mathrm{C}$ & 55 & 43.0 \\
$22^{\circ} \mathrm{C}-24^{\circ} \mathrm{C}$ & 14 & 10.9 \\
Higher than $24^{\circ} \mathrm{C}$ & 2 & 1.6 \\
Not using radiator for heating & 35 & 27.3 \\
\hline
\end{tabular}

Respondents' practices in terms of watering plants in the garden or on the balcony were examined and, as it appears in Table 30, most parents (40.6\%) watered plants at night and a considerable share $(29.7 \%)$ watered them in the afternoon. At the same time, an appreciable share of $17.2 \%$ watered plants whenever it was convenient.

Table 30. Percentages regarding the times that respondents water their plants.

\begin{tabular}{ccccc}
\hline Morning & Midday & Afternoon & Night & Whenever It Is Convenient \\
\hline 12.5 & 0.0 & 29.7 & 40.6 & 17.2 \\
\hline
\end{tabular}


Respondents were then asked how often they took the stairs in their building. According to Table $31,39.1 \%$ of participants reported that they always take the stairs, as opposed to $7 \%$ who stated they never used the stairs. Moreover, a high percentage of $42.2 \%$ lived in a single-family house.

Table 31. Percentages in terms of the frequency of using the stairs.

\begin{tabular}{ccccc}
\hline Never & Once or Twice a Day & 3-4 Times a Day & Always & Living in a Single-Family House \\
\hline 7.0 & 6.3 & 5.5 & 39.1 & 42.2 \\
\hline
\end{tabular}

\subsubsection{Parents' Trust in Bodies}

Parents were asked how much they trust various bodies in order to participate in actions aiming to address issues that are related to life quality and other everyday issues. To examine the existence of a statistical difference among responses, the non-parametric Freidman test was conducted (Table 32). It was indicated that parents trusted mostly scientists (mean rank 7.29), followed by citizen groups (mean rank 6.34), whereas political parties were ranked in the last position (mean rank 2.26).

Table 32. The application of the non-parametric Friedman test for ranking parents' trust in bodies in order to participate in actions aimed at improving daily life and life quality.

\begin{tabular}{cc}
\hline & Mean Rank \\
\hline European Union & 4.86 \\
Government & 3.40 \\
Local authorities & 5.16 \\
Political parties & 2.26 \\
Non-governmental organizations & 4.83 \\
Environmental groups & 6.33 \\
Citizen groups & 6.34 \\
Scientists & 7.29 \\
The media & 4.53 \\
\hline
\end{tabular}

$\mathrm{N}=128$, Chi-Square $=397.697, \mathrm{df}=8, p<0.001$.

\subsubsection{Information Sources Parents Use for Their Daily Information}

Finally, parents were required to evaluate various information sources in terms of their contribution to the information they provide on daily matters. Again, the non-parametric Friedman test was used to scrutinize participants' responses. As presented in Table 33, the Internet was the most preferred information source (mean rank 6.95), followed by family and friends (mean rank 6.88), and national television networks (mean rank 6.07). Conversely, magazines (mean rank 3.00) and local radio networks (mean rank 4.93) were the least preferred information sources.

Table 33. Hierarchy of the information sources parents use on daily basis.

\begin{tabular}{cc}
\hline & Mean Rank \\
\hline Family and friends & 6.88 \\
Local television networks & 5.41 \\
National television networks & 6.07 \\
Local radio networks & 4.93 \\
National radio networks & 5.10 \\
Local newspapers & 5.22 \\
National newspapers & 5.52 \\
Magazines & 3.00 \\
Internet & 6.95 \\
Seminars-conferences & 5.92 \\
\hline $\mathrm{N}=128$, Chi-Square $=397.697, \mathrm{df}=8, p<0.001$.
\end{tabular}




\section{Conclusions-Discussion}

The purpose of the present study was to examine the attitudes and views of fifth-and sixth-grade students and their parents on energy and water saving as well as environmental protection in the municipality of Orestiada in Greece. It was striking that only half of the students were satisfied with the state of the natural environment, while parents perceived that the quality of the environment affects their life. The views of the parents on the influence of environmental quality were somewhat to be expected, since the study of Vardoulakis et al. [70] indicated that the environment has strong effects on human health. Moreover, the majorities of students and parents considered that our planet's natural resources are limited. Hence, participants seemed to acknowledge the importance of managing natural resources in order to delay as much as possible the exhaustion of their reserves. This resonates with Gajibo [71], who claimed that a country can promote economic growth by establishing an energy policy framework that focuses on the rational management of resources and alternative energy sources.

Students' environmental knowledge is greatly affected by the stimuli in their close and wider environment. In specific, school and family make the greatest contribution to their environmental knowledge. However, the percentage of students having participated in environmental programs is considered rather low if one considers that these programs can spark students' interest in nature. Therefore, the conduct of environmental education programs along with training teachers on environmental topics are necessary to create pro-environmental attitudes among students so that they later become environmentally responsible consumers [3].

Parents' preferences for information sources revealed the important role of the Internet, family, and friends, as well as television and newspapers in disseminating information on daily topics including environmental ones. It is also worthwhile to observe that parents trust scientists, citizen groups, and environmental groups in order to participate in actions that aim at addressing issues relating to life quality and everyday life. Conversely, parents expressed the lowest level of trust in political parties. Given that parents exhibited an adequate level of willingness to act, one could state that this willingness is related to their desire to contribute to the solution of environmental problems. This finding is consistent with studies showing that love and respect for nature can motivate individuals to act and behave responsibly in order to protect the environment [72].

Both parents and students have similar energy saving habits as both have adopted the habits of turning the tap off during brushing teeth or shaving, taking baths without filling the bathtub with water, turning off the shower while lathering up, pulling down the shutters at night, and switching off the lights when leaving a room. It is also noteworthy that both parents and students expressed the same habit patterns in terms of watering plants in the garden or on the balcony, with most of them preferring to water plants in the afternoon or at night, that is, the time that some quantity of water can be saved. A relevant study showed that the stimuli that the students receive in their close and wider environment play a critical role in their environmental behavior and attitudes [73], because children tend to imitate and adopt the behaviors they see in their environment. From this perspective, it can be suggested that in this study parents' behavior was imitated by their children.

The student habit of putting on an additional layer of clothes when feeling cold instead of setting the thermostat to a higher temperature is another point that ought to be discussed. Most importantly, this practice suggests that the students adopted it in the context of "energy education." Hence, it is possible that students who are aware of the simple habits required to save energy are likely to exhibit pro-environmental behaviors in the form of energy saving. It is also important to point out that while environmental education aims at changing human behavior and helps students adopt simple daily habits, the student's family environment plays an equally important role as it can set a good example for children [74].

More specifically, parents serve as examples and affect their children's environmental views and attitudes. This was confirmed in our study where students and parents were found to have similar views and attitudes. For instance, both students and parents have developed the habits of switching off televisions and laptops using the power button and setting the thermostat to temperatures between 
$18^{\circ} \mathrm{C}$ and $22^{\circ} \mathrm{C}$. It can thus be seen that in this study parents' pro-environmental behavior influenced their children and induced them to adopt energy saving habits. This is in line with Cheng and Monroe [75], who indicated that contact with nature together with positive environmental attitudes in the family have a positive effect on children and can drive them to adopt pro-environmental behaviors. For this reason, parents should provide their children with experiences that involve environmental education and awareness [10]. With regard to the above arguments, it is inferred that parents and the wider family environment have a strong effect on children's behavior [30].

However, in this study only a small share of students went to school on foot or used public transport. This finding is inconsistent with the study of Vicente-Molina et al. [76], in which most students went to school on foot or by bicycle, expressing in this way their pro-environmental behavior. Given the inconsistency of the findings, a future study should investigate the factors that affect students' decisions to use specific means of transport to go to school. It is possible that safety issues and waking up late contribute to this decision.

Beside parents who have a notable influence on children's environmental behavior, environmental education and education on sustainability can not only shape pro-environmental behaviors but also lead students to exert efforts to achieve sustainable development in the future. Therefore, the role of the school should be emphasized [77], as it can affect students' lifestyles and daily behavior [78]. At the same time, teachers are required to play a crucial part and their training on environmental topics is deemed of the utmost importance. The primary task of teachers ought to be the planning of environmental programs that aim at connecting students with nature. In this way, through environmental education and with the guidance of teachers who have environmental awareness, students will be able to realize their own role in the protection and improvement of the environment [43].

The form of school is gradually changing and opens towards society. As an institution, school should be compatible with the evolution of society and, to that end, environmental education must constantly reform its content, objectives, and methods so that students are continuously encouraged to adopt environmentally responsible behaviors. Nevertheless, environmentally responsible behaviors result from the interaction between endogenous and exogenous factors, which follow different functioning from person to person. This can explain why in some cases pro-environmental attitudes are not translated into pro-environmental behaviors [78].

To conclude, the students and parents who participated in this study appeared to have awareness about the environment and its problems, and their perceptions were translated into actions as they have adopted to a significant extent energy saving practices. If the institutions of family and education follow a common path of action, common education programs targeted at both parents and students will be feasible. Such programs can enhance recycling habits, as this study indicated that only half of the students recycle and very few go to school on foot or use their bicycles. Moreover, it has been clearly shown that the family ought to express positive environmental behaviors so that children have a good example to follow.

This study sought to examine the environmental behaviors and attitudes among students and their parents, and the findings are representative for the conurbation of Orestiada. It was not, however, possible to compare the findings of students and parents, as such an analysis would violate respondents' personal data. A parameter that has not been examined in this study but should be the focus in future research is parents' ambitions and expectations for their children's academic studies and future careers, even though this might seem too distant. In addition, a future research work could examine environmental education programs at school and investigate the effect of these programs on students' family environments as well as explore teacher training on environmental topics. In this way, it will become possible to gain insights into the attitudes of a higher share of the population while reinforcing the actions of schools and the cooperation between schools and the wider social environment.

Author Contributions: Data curation, I.Z.; methodology—formal analysis, K.I.; supervision, G.T.; validation, V.A.; writing-review \& editing, E.K. All authors have read and agreed to the published version of the manuscript.

Funding: This research received no external funding. 
Conflicts of Interest: The authors declare no conflict of interest.

\section{References}

1. Dincer, I. Renewable energy and sustainable development: A crucial review. Renew. Sustain. Energy Rev. 2000, 4, 157-175. [CrossRef]

2. Wolsink, M. Wind power implementation: The nature of public attitudes: Equity and fairness instead of 'backyard motives. Renew. Sustain. Energy Rev. 2007, 11, 1188-1207. [CrossRef]

3. Zyadin, A.; Puhakka, A.; Ahponen, P.; Cronberg, T.; Pelkonen, P. School students' knowledge, perceptions, and attitudes toward renewable energy in Jordan. Renew. Energy 2012, 45, 78-85. [CrossRef]

4. Lefkeli, S.; Manolas, E.; Ioannou, K.; Tsantopoulos, G. Socio-Cultural Impact of Energy Saving: Studying the Behaviour of Elementary School Students in Greece. Sustainability 2018, 10, 737. [CrossRef]

5. Karatayev, M.; Clarke, M.L. A review of current energy systems and green energy potential in Kazakhstan. Renew. Sustain. Energy Rev. 2016, 55, 491-504. [CrossRef]

6. Karachristos, C.; Galatsidas, S. Sustainable management of forest ecosystems and climate change. In Topics on Forestry and Management of the Environment and Natural Resources; Forestry and Management of the Environment and Natural Resources: Orestiada Greece, 2015; pp. 110-120.

7. Katzi-Beltran, C. Education on the Environment and Sustainable Development as a Pedagogical Framework in Primary and Preschool Education; Frederick Research Centre: Nicosia, Cyprus, 2013.

8. Estrada-Vidal, L.I.; Tójar-Hurtado, J.-C. College Student Knowledge and Attitudes Related to Sustainability Education and Environmental Health. Procedia Soc. Behav. Sci. 2017, 237, 386-392. [CrossRef]

9. Valderrama-Hernández, R.; Alcántara, L.; Limón, D. The Complexity of Environmental Education: Teaching Ideas and Strategies from Teachers. Procedia Soc. Behav. Sci. 2017, 237, 968-974. [CrossRef]

10. Vassiloudis, I. Parents and environmental education: The demographic variables as factors affecting the shaping of pro-environmental behaviors. Educ. Sci. 2010, 2, 65-75.

11. Loukas, A.; Vasiliades, L.; Dalezios, N.R. Potential climate change impacts on flood producing mechanisms in southern British Columbia, Canada using the CGCMA1 simulation results. J. Hydrol. 2002, 259, 163-188. [CrossRef]

12. EU. Directive (EU) 2018/2002 of the European Parliament and of the Council of 11 December 2018 amending Directive 2012/27/EU on energy efficiency. Off. J. Eur. Union 2018, L 328, 210-230.

13. Dubois, G.; Sovacool, B.; Aall, C.; Nilsson, M.; Barbier, C.; Herrmann, A.; Bruyère, S.; Andersson, C.; Skold, B.; Nadaud, F.; et al. It starts at home? Climate policies targeting household consumption and behavioral decisions are key to low-carbon futures. Energy Res. Soc. Sci. 2019, 52, 144-158. [CrossRef]

14. Chen, W.-M.; Kim, H.; Yamaguchi, H. Renewable energy in eastern Asia: Renewable energy policy review and comparative SWOT analysis for promoting renewable energy in Japan, South Korea, and Taiwan. Energy Policy 2014, 74, 319-329. [CrossRef]

15. Arabatzis, G.; Petridis, K.; Galatsidas, S.; Ioannou, K. A demand scenario based fuelwood supply chain: A conceptual model. Renew. Sustain. Energy Rev. 2013, 25, 687-697. [CrossRef]

16. Kaldellis, J.K. Social attitude towards wind energy applications in Greece. Energy Policy 2005, 33, 595-602. [CrossRef]

17. Tampakis, S.; Tsantopoulos, G.; Arabatzis, G.; Rerras, I. Citizens' views on various forms of energy and their contribution to the environment. Renew. Sustain. Energy Rev. 2013, 20, 473-482. [CrossRef]

18. Hertwich, E.G. Life Cycle Approaches to Sustainable Consumption: A Critical Review. Environ. Sci. Technol. 2005, 39, 4673-4684. [CrossRef]

19. Tukker, A.; Jansen, B. Environmental Impacts of Products: A Detailed Review of Studies. J. Ind. Ecol. 2006, 10, 159-182. [CrossRef]

20. Hertwich, E.G.; Peters, G.P. Carbon Footprint of Nations: A Global, Trade-Linked Analysis. Environ. Sci. Technol. 2009, 43, 6414-6420. [CrossRef]

21. Pacala, S. Stabilization Wedges: Solving the Climate Problem for the Next 50 Years with Current Technologies. Science 2004, 305, 968-972. [CrossRef]

22. Hungerford, H.R.; Volk, T.L. Changing Learner Behavior Through Environmental Education. J. Environ. Educ. 1990, 21, 8-21. [CrossRef] 
23. Dietz, T.; Gardner, G.T.; Gilligan, J.; Stern, P.C.; Vandenbergh, M.P. Household actions can provide a behavioral wedge to rapidly reduce US carbon emissions. Proc. Natl. Acad. Sci. USA 2009, 106, 18452-18456. [CrossRef] [PubMed]

24. Wilkinson, P.; Smith, K.R.; Davies, M.; Adair, H.; Armstrong, B.G.; Barrett, M.; Bruce, N.; Haines, A.; Hamilton, I.; Oreszczyn, T.; et al. Public health benefits of strategies to reduce greenhouse-gas emissions: Household energy. Lancet 2009, 374, 1917-1929. [CrossRef]

25. Hwang, Y.-H.; Kim, S.-I.; Jeng, J.-M. Examining the Causal Relationships Among Selected Antecedents of Responsible Environmental Behavior. J. Environ. Educ. 2000, 31, 19-25. [CrossRef]

26. Ishak, M.H.; Sipan, I.; Sapri, M.; Mar Iman, A.H.; Martin, D. Estimating potential saving with energy consumption behaviour model in higher education institutions. Sustain. Environ. Res. 2016, 26, 268-273. [CrossRef]

27. Grob, A. A structural model of environmental attitudes and behaviour. J. Environ. Psychol. 1995, 15, $209-220$. [CrossRef]

28. Kuhlemeier, H.; Van Den Bergh, H.; Lagerweij, N. Environmental Knowledge, Attitudes, and Behavior in Dutch Secondary Education. J. Environ. Educ. 1999, 30, 4-14. [CrossRef]

29. Kousoulas, G. Approch to Environmental Education; Institute of Urban and Rural Sociology, National Center of Social Research: Athens, Greece, 2008.

30. Sadik, F.; Sadik, S. A Study on Environmental Knowledge and Attitudes of Teacher Candidates. Procedia Soc. Behav. Sci. 2014, 116, 2379-2385. [CrossRef]

31. Choeisuwan, V. Association of Interest in Receiving Information, Society's Support and Energy Saving Responsibility with Energy-saving behavior of the Nursing Students at the Royal Thai Navy College of Nursing. Procedia Soc. Behav. Sci. 2015. [CrossRef]

32. Skanavi, K. Environment and Communication. The Right to Choose; Kaleidoskopio: Athens, Greece, 2004.

33. Lombardi, D.; Sinatra, G.M.; Nussbaum, E.M. Plausibility reappraisals and shifts in middle school students' climate change conceptions. Learn. Instr. 2013. [CrossRef]

34. Petrasek MacDonald, J.; Harper, S.L.; Cunsolo Willox, A.; Edge, V.L. Rigolet Inuit Community Government A necessary voice: Climate change and lived experiences of youth in Rigolet, Nunatsiavut, Canada. Glob. Environ. Chang. 2013, 23, 360-371. [CrossRef]

35. Çelikler, D.; Aksan, Z. The opinions of secondary school students in Turkey regarding renewable energy. Renew. Energy 2015. [CrossRef]

36. Flogaitis, E. Education on the Environment and Sustainability; Greek Letters: Athens, Greece, 2006.

37. Tsaliki, E. Factors Which Influence the Intention of Older Primary School Pupils to Act Environmentally. The Case of the Forest; Aristotle University of Thessaloniki (AUTH), Faculty of Education: Thessaloniki, Greece, 2006.

38. Chan, K.K.W. Environmental attitudes and behaviour of secondary school students in Hong Kong. Environmentalist 1996, 16, 297-306. [CrossRef]

39. Heyl, M.; Díaz, E.M.; Cifuentes, L. Environmental attitudes and behaviors of college students: A case study conducted at a chilean university. Rev. Latinoam. Psicol. 2014. [CrossRef]

40. Negev, M.; Sagy, G.; Garb, Y.; Salzberg, A.; Tal, A. Evaluating the environmental literacy of Israeli elementary and high school students. J. Environ. Educ. 2008, 39, 3-20. [CrossRef]

41. DeWaters, J.; Qaqish, B.; Graham, M.; Powers, S. Designing an energy literacy questionnaire for middle and high school youth. J. Environ. Educ. 2013. [CrossRef]

42. Budak, D.B.; Budak, F.; Zaimoglu, Z.; Kekec, S.; Sucu, M.Y. Behaviour and Attitudes of Students Towards Environmental Issues at Faculty of Agriculture, Turkey. J. Appl. Sci. 2005. [CrossRef]

43. Sioki, E. Students' Attitudes Towards the Environment and Environmental Problems through Their Participation in Environmental Education Programs at School. Ph.D. Thesis, University of the Aegean, Rhodes, Greece, 2012.

44. Bonnett, M.; Williams, J. Environmental education and primary children's attitudes towards nature and the environment. Camb. J. Educ. 1998. [CrossRef]

45. Kopnina, H. Kids and cars: Environmental attitudes in children. Transp. Policy 2011. [CrossRef]

46. Oliver, M.; Badland, H.; Mavoa, S.; Witten, K.; Kearns, R.; Ellaway, A.; Hinckson, E.; Mackay, L.; Schluter, P.J. Environmental and socio-demographic associates of children's active transport to school: A cross-sectional investigation from the URBAN Study. Int. J. Behav. Nutr. Phys. Act. 2014. [CrossRef] 
47. Nasrudin, N.; Nor, A.R.M. Travelling to School: Transportation Selection by Parents and Awareness towards Sustainable Transportation. Procedia Environ. Sci. 2013. [CrossRef]

48. Chawla, L. Life paths into effective environmental action. J. Environ. Educ. 1999. [CrossRef]

49. Wells, N.; Lekies, K. Nature and the Life Course: Pathways from Childhood Nature Experiences to Adult Environmentalism. Child. Youth Environ. 2006, 16, 1-24.

50. Collado, S.; Staats, H.; Corraliza, J.A. Experiencing nature in children's summer camps: Affective, cognitive and behavioural consequences. J. Environ. Psychol. 2013. [CrossRef]

51. Evans, G.W.; Brauchle, G.; Haq, A.; Stecker, R.; Wong, K.; Shapiro, E. Young children's environmental attitudes and behaviors. Environ. Behav. 2007. [CrossRef]

52. Veselinovska, S.S.; Osogovska, T.L. Engagement of Students in Environmental Activities in School. Procedia Soc. Behav. Sci. 2012, 46, 5015-5020. [CrossRef]

53. Symeou, L.; Zachariou, A.; Valanides, N. Parents' participation in environmental action programs in the community: The experience of parents in Cyprus. Educ. Sci. 2007, 4, 197-211.

54. Leppänen, J.M.; Haahla, A.E.; Lensu, A.M.; Kuitunen, M.T. Parent-child similarity in environmental attitudes: A pairwise comparison. J. Environ. Educ. 2012, 43, 162-176. [CrossRef]

55. Pratt, M.W.; Norris, J.E.; Alisat, S.; Bisson, E. Earth mothers (and fathers): Examining generativity and environmental concerns in adolescents and their parents. J. Moral Educ. 2013, 42, 12-27. [CrossRef]

56. Walker, W.E.; Harremoës, P.; Rotmans, J.; van der Sluijs, J.P.; van Asselt, M.B.A.; Janssen, P.; Krayer von Krauss, M.P. Defining Uncertainty: A Conceptual Basis for Uncertainty Management in Model-Based Decision Support. Integr. Assess. 2003. [CrossRef]

57. Palmer, J.A. Environmental Thinking in the Early Years: Understanding and misunderstanding of concepts related to waste management. Environ. Educ. Res. 1995. [CrossRef]

58. Paraschidou, A. Comparative Research of Students' and Parents' Views and Attitudes Towards Recycling. The Case of Primary Education in the Municipality of Orestiada. Master's Thesis, Democritus University of Thrace, Orestiada, Greece, 2018.

59. Thomas, G.O.; Fisher, R.; Whitmarsh, L.; Milfont, T.L.; Poortinga, W. The impact of parenthood on environmental attitudes and behaviour: A longitudinal investigation of the legacy hypothesis. Popul. Environ. 2018. [CrossRef] [PubMed]

60. Papadopoulou, S.-D.; Kalaitzoglou, N.; Psarra, M.; Lefkeli, S.; Karasmanaki, E.; Tsantopoulos, G. Addressing Energy Poverty through Transitioning to a Carbon-Free Environment. Sustainability 2019, 11, 2634. [CrossRef]

61. Martinho, G.; Magalhães, D.; Pires, A. Consumer behavior with respect to the consumption and recycling of smartphones and tablets: An exploratory study in Portugal. J. Clean. Prod. 2017. [CrossRef]

62. Gram-Hanssen, K. Teenage consumption of information and communication technology. In Proceedings of the 2005 ECEEE Summer Study, Mandelieu La Napoule, France, 30 May-4 June 2005.

63. Grønhøj, A.; Thøgersen, J. Like father, like son? Intergenerational transmission of values, attitudes, and behaviours in the environmental domain. J. Environ. Psychol. 2009. [CrossRef]

64. Vaughan, C.; Gack, J.; Solorazano, H.; Ray, R. The Effect of Environmental Education on Schoolchildren, Their Parents, and Community Members: A Study of Intergenerational and Intercommunity Learning. J. Environ. Educ. 2003, 34, 12-21. [CrossRef]

65. Duvall, J.; Zint, M. A review of research on the effectiveness of environmental education in promoting Lntergenerational learning. J. Environ. Educ. 2007. [CrossRef]

66. Fischhoff, B. Environmental Cognition, Perceptions, and Attitudes. In International Encyclopedia of the Social $\mathcal{E}$ Behavioral Sciences; Elsevier: Amsterdam, The Netherlands, 2001; pp. 4596-4602.

67. Albuam, G.; Oppenheim, A.N. Questionnaire Design, Interviewing and Attitude Measurement. J. Mark. Res. 1993. [CrossRef]

68. Vamvoukas, M. Introduction to Psycho-pedagogical Research and Methodology; Grigoris: Athens, Greece, 1998.

69. Freund, R.J.; Wilson, W.J.; Mohr, D.L. Data and Statistics. In Statistical Methods; Elsevier: Amsterdam, The Netherlands, 2010; pp. 1-65.

70. Vardoulakis, S.; Dimitroulopoulou, C.; Thornes, J.; Lai, K.M.; Taylor, J.; Myers, I.; Heaviside, C.; Mavrogianni, A.; Shrubsole, C.; Chalabi, Z.; et al. Impact of climate change on the domestic indoor environment and associated health risks in the UK. Environ. Int. 2015, 85, 299-313. [CrossRef]

71. Gajibo, A.I. Developing a Framework for Generation of Energy from Waste through Anaerobic Digestion in Nigeria: Case Study-Abuja. Master's Thesis, University of Abertay Dundee, Dundee, UK, 2016. 
72. Gilligan, C. Psychological Theory and Women's Development. In In a Different Voice; Harvard University Press: Cambridge, MA, USA, 1982; ISBN 0674445430.

73. de Leeuw, A.; Valois, P.; Ajzen, I.; Schmidt, P. Using the theory of planned behavior to identify key beliefs underlying pro-environmental behavior in high-school students: Implications for educational interventions. J. Environ. Psychol. 2015, 42, 128-138. [CrossRef]

74. Cheng, J.C.H.; Monroe, M.C. Connection to nature: Children's affective attitude toward nature. Environ. Behav. 2012. [CrossRef]

75. Vicente-Molina, M.A.; Fernández-Sáinz, A.; Izagirre-Olaizola, J. Environmental knowledge and other variables affecting pro-environmental behaviour: Comparison of university students from emerging and advanced countries. J. Clean. Prod. 2013. [CrossRef]

76. Oncu, E.C.; Unluer, E. Environmental Views and Awareness of Preschool Teacher Candidates. Procedia Soc. Behav. Sci. 2015. [CrossRef]

77. Zsóka, Á.; Szerényi, Z.M.; Széchy, A.; Kocsis, T. Greening due to environmental education? Environmental knowledge, attitudes, consumer behavior and everyday pro-environmental activities of Hungarian high school and university students. J. Clean. Prod. 2013, 48, 126-138. [CrossRef]

78. Karasmanaki, E.; Tsantopoulos, G. Exploring future scientists' awareness about and attitudes towards renewable energy sources. Energy Policy 2019, 131, 111-119. [CrossRef]

(C) 2020 by the authors. Licensee MDPI, Basel, Switzerland. This article is an open access article distributed under the terms and conditions of the Creative Commons Attribution (CC BY) license (http://creativecommons.org/licenses/by/4.0/). 